\title{
Spitstyd: Uitgesoekte rubrieke
}

\begin{tabular}{|c|c|}
\hline \multicolumn{2}{|c|}{$\begin{array}{l}\text { Book Title: } \\
\text { Spitstyd: Uitgesoekte } \\
\text { rubrieke }\end{array}$} \\
\hline $\begin{array}{l}\text { SPiI } \\
\text { Uigessoe } \\
\text { WII } \\
\text { JOR }\end{array}$ & $\begin{array}{l}\text { TYD } \\
\text { rubrieke } \\
\text { ELM } \\
\text { AAN }\end{array}$ \\
\hline $\begin{array}{l}\text { Author: } \\
\text { Wilhelm Jord }\end{array}$ & \\
\hline $\begin{array}{l}\text { ISBN: } \\
978-1-92018\end{array}$ & $-35-1$ \\
\hline $\begin{array}{l}\text { Publisher: } \\
\text { Litera Publika } \\
\text { (Pretoria } 201\end{array}$ & ) \\
\hline $\begin{array}{l}\text { Review Title } \\
\text { Spitstyd: Uitg }\end{array}$ & soekte rubrieke \\
\hline $\begin{array}{l}\text { Reviewer: } \\
\text { Belia A.J. van }\end{array}$ & der Merwe ${ }^{1}$ \\
\hline $\begin{array}{l}\text { Affiliation: } \\
{ }^{1} \text { Private, Sout }\end{array}$ & Africa \\
\hline $\begin{array}{l}\text { Email: } \\
\text { bkjvdm@xsin }\end{array}$ & t.co.za \\
\hline $\begin{array}{l}\text { Postal addre } \\
\text { Private Bag X } \\
\text { Potchefstroo } \\
\text { South Africa }\end{array}$ & $\begin{array}{l}\text { s: } \\
001 \\
2520\end{array}$ \\
\hline $\begin{array}{l}\text { How to cite th } \\
\text { Van der Merv } \\
\text { 'Spitstyd: Uit } \\
\text { rubrieke', Lite } \\
\text { Art. \#144, } 2 \text { p } \\
\text { dx.doi.org/10 } \\
\text { v34i1.144 }\end{array}$ & $\begin{array}{l}\text { is book review: } \\
\text { e, B.A.J., } \\
\text { esoekte } \\
\text { ator } 34(1) \text {, } \\
\text { ages. http:// } \\
\text { 4102/lit. }\end{array}$ \\
\hline $\begin{array}{l}\text { Copyright: } \\
\text { (C) 2013. The } \\
\text { Licensee: AOS } \\
\text { OpenJournals } \\
\text { is licensed un } \\
\text { Creative Com } \\
\text { Attribution Li }\end{array}$ & $\begin{array}{l}\text { Authors. } \\
\text { IS } \\
\text { This work } \\
\text { der the } \\
\text { nons } \\
\text { ense. }\end{array}$ \\
\hline Read online: & \\
\hline 口保回 & $\begin{array}{l}\text { Scan this QR } \\
\text { code with your } \\
\text { smart phone or } \\
\text { mobile device } \\
\text { to read online. }\end{array}$ \\
\hline
\end{tabular}

Spitstyd: Uitgesoekte rubrieke is 'n keur uit Wilhelm Jordaan se rubrieke wat oor die jare in Beeld en Die Burger verskyn het. Die 126 rubrieke wat in die bundel opgeneem is, is gegroepeer in vier afdelings wat elkeen 'n bepaalde verhoudingsaspek as opskrif het: Jy met jouself; Jy en die ander; Jy en die samelewing en Jy en die groot misterie. Hieroor verantwoord Jordaan hom as volg: 'Alles wat ek bedink, is altyd gedefinieer in 'n bepaalde verhouding. Dis van die kosbaarste goed wat daar is' (Beeld 11 November 2011).

As suksesvolle joernalis neem Wilhelm Jordaan in die sestigerjare 'n jaar studieverlof om 'n honneursgraad in sielkunde te doen. Hierna word hy eers dosent in sielkunde, later professor en hoof van die departement by die Universiteit van Suid-Afrika. Op versoek van 'n eertydse kollega uit sy koerantjare begin hy in 1987 'n sielkunderubriek vir Beeld skryf. Mettertyd verander die invalshoek van die rubrieke egter sodanig dat dit nie meer tot die sielkunde beperk is nie, maar 'n groot aantal wyd uiteenlopende onderwerpe onder die loep neem.

Aktuele sake, daaglikse nuusberigte, gebeure uit sy persoonlike lewe, 'n gedig, 'n verhaal, 'n skildery, en nog vele meer dien as vertrekpunt vir sy rubrieke. Reeds met die eerste deurblaai van die bundel vang die interessante en vindingryke woordspeling in sommige titels die leser se oog, byvoorbeeld: Wie í ek as ek myself is?; Oombliklik die bliksem in!; Ek het, daarom is ek; Toe sien die wetenskap dat dit goed was; Gebed geweeg, ek te lig bevind; God eet uie. Die verwagting waarmee 'n mens aan hierdie rubrieke begin lees, word dan ook regdeur die bundel nooit teleurgestel nie.

Die rubrieke wissel in lengte, maar elkeen vorm 'n afgeronde geheel. Hulle toon duidelik dat die skrywer nie alleen grondige kennis het van 'n groot verskeidenheid onderwerpe nie, maar dat hy ook oor besondere insig in alle aspekte van die menslike bestaan beskik. So skryf hy byvoorbeeld: 'In ons wêreld is dit swaar om te wees wat jy is.' (bl. 2) en die mens se oudste behoefte is 'om van geweet te wees, dat jy saak maak en nie bloot 'n weggesteekte, ongelese voetnota in die lewensjoernaal is nie' (bl. 127). Gesonde verstand behels vir hom "n gesogte, rustige wysheid wat jou help om klein naalde van betekenis in enorme hooimiedens van snert te bespeur...' (bl. 18).

Dit is van meet af aan duidelik dat hier ' $n$ wydbelese skrywer aan die woord is. Hy lig sy stellings toe met voorbeelde uit die wêreldliteratuur, die Afrikaanse letterkunde en veral die digkuns. Klassieke werke soos dié van die Romeinse satirikus Juvenalis en die Romeinse digter Horatius (bl. 139) vorm deel van sy verwysingsraamwerk, maar ook karaktertjies uit kinderstories soos Piglet en Winnie the Pooh. Jordaan beskou trouens 'daardie beertjie wat so' $n$ bietjie dinkverskrik is en moeg raak as woorde rek en rek' as sy gunstelingfilosoof.

Naas die groot aantal gedigte uit die Afrikaanse poësieskat wat hy aanhaal, bespreek en verduidelik, verskyn daar ook in sommige van die rubrieke van Jordaan se eie gedigte - 'n ekstra bonus vir die leser. Soos byvoorbeeld in Ná al die jare: Jammer, Meneer! (bl. 19):

\author{
Toe ek kind was in die winter \\ het ek fiets gery \\ om die hartseer \\ uit my lyf te kry. \\ Het iemand agterna \\ oor my oё uitgevra \\ het ek die weer \\ die wind van voor \\ blameer (bl. 20)
}

Elke rubriek bied aan die leser stof tot nadenke. Jordaan skram nie weg daarvan om hom uit te laat oor kontroversiële sake soos byvoorbeeld lyfstraf, werkende vroue, korrupsie, selfmoord, evolusie en vele ander nie, maar dit is altyd 'n goed beredeneerde, oortuigende en koelkop mening. Na aanleiding van die feit dat mense se belewenis van God radikaal verskil, waarsku hy byvoorbeeld: 
En begryp ook, terselfdertyd, dat die egtheid van ' $n$ ander mens se Godsbelewenisse nie gemeet kan word aan die meetsnoere van die metafore, of die soort kerkspraak wat jóú aanspreek nie. (bl. 157)

Dit is egter nie net ernstige en swaarwigtige onderwerpe wat bespreek word nie. In sommige rubrieke staan die humor voorop, soos byvoorbeeld in Stilte in die hof! waar vertel word hoe 'n jong hofkonstabel kort en kragtig, maar baie doeltreffend 'n lawaaierige groep mense tot stilte dwing.

In 'n aantal van die rubrieke kry die leser ook 'n persoonlike blik op die skrywer wanneer sy gesinslede - sy pa, sy vrou, kinders en kleinkinders - ter sprake kom. So skryf hy oor sy vrou as ywerige tuinier:

Sy sê wanneer sy sterf, moet ons haar as in die tuin strooi. Ook op die komposhoop waar ek werk? vra ek plaend. Wat moet ek dan maak met al die asblomme en asters wat opkom? Net waar ek kyk, is jy! (bl. 47)

$\mathrm{Na}$ die lees van Spitstyd: Uitgesoekte rubrieke kan 'n mens heeltemal met Joan Hambidge saamstem dat die benaming volksghoeroe, soos iemand Wilhelm Jordaan by geleentheid genoem het, 'n beskrywing is wat hom perfek opsom:

Raad of antwoorde is daar nooit volledig nie, maar as wyse volksghoeroe verduidelik hy hoe ons moet reageer op pynlike of onverwagse ervarings wat 'n mens se lewe kan verander. (bl. ii)

Gereelde lesers van Wilhelm Jordaan se koerantrubrieke sowel as lesers wat met hierdie bundel vir die eerste keer met sy skrywes kennis maak, sal ewe veel genot put uit die lees van Spitstyd: Uitgesoekte rubrieke. Dit sal ook geen leser onaangeraak laat nie. 